\title{
Public Opinion and Attitude toward the Military and Democratic Consolidation in Turkey
}

Armed Forces \& Society 20I5, Vol. 4I(2) 282-306

(C) The Author(s) 2013

Reprints and permission: sagepub.com/journalsPermissions.nav DOI: $10.1177 / 0095327 X 13504573$ afs.sagepub.com @SAGE

\section{Zeki Sarigil $^{\prime}$}

\begin{abstract}
The political influence of the Turkish military has substantially declined in the last decade, triggered by the European Union's decision during the Helsinki Summit in 1999 to grant candidacy status to Turkey. This study illuminates Turkey's democratization process in the post-Helsinki period by empirically analyzing a relatively underinvestigated aspect of civil-military relations: public opinion and attitude toward the military and civil-military issues. Empirical analyses, based on original and comprehensive public opinion data, indicate that despite impressive reforms and improvements in the legal and institutional structures in Turkish civil-military relations in the past ten years, democratic transformation in the political culture has been lagging behind. This gap is likely to complicate democratization process in Turkey. The article also provides a discussion of broader theoretical and practical implications of empirical findings.
\end{abstract}

\section{Keywords}

public opinion, civil-military relations, Turkish military, political culture, democratic consolidation

In the civil-military relations literature, we see the dominance of dichotomous approaches, which assume a power relationship between two sides: civil and military. As a result, studies on civil-military relations focus on political and military elites and

\footnotetext{
' Department of Political Science, Bilkent University, Bilkent, Ankara, Turkey
}

\section{Corresponding Author:}

Zeki Sarigil, Department of Political Science, Bilkent University, 06800 Bilkent, Ankara, Turkey.

Email: sarigil@bilkent.edu.tr 
their interactions. The civil-military dichotomy, however, lumps society with political elites on the civilian side vis-à-vis the military and therefore ignores the autonomous causal role played by the social realm. ${ }^{1}$ As Schiff observes,

[t]he current civil-military relations literature does not consider the citizenry, but relies instead on political institutions as the main "civil" component of analysis. Although the relationship of civil institutions to the military is indeed important, it only partially reflects the story of civil-military relations. ${ }^{2}$

In contrast to the dichotomous approach, Schiff proposes the "concordance theory," which treats the citizenry as a third and important partner in civil-military relations, distinct from the military and political elites. Concordance theory simply expects that if there is concordance or harmony among the three spheres (i.e., the military, the political elite, and the citizenry) regarding the composition of the officer corps, political decision-making processes, recruitment methods, and military style, then domestic military intervention will be less likely. ${ }^{3}$

Inspired by that theory, this study focuses on the role of social and cultural factors in civil-military relations. This subject deserves more consideration than it has been given because public opinion and attitudes vis-à-vis the military have direct consequences for democratic control of the armed forces and therefore for democratic consolidation. As Huntington notes, "the standing of the officer corps and its leaders with public opinion and the attitudes of broad section or categoric groups in society toward the military are key elements in determining military influence." 4 Huntington argues that any change in the degree of the prestige and popularity of the officer corps and its leaders in society should have some direct impact on the military's political influence and therefore on the possibility of conflict between the military and civilian spheres. ${ }^{5}$ In a similar fashion, other observers suggest that the popularity of the military might create a favorable environment for an interventionist military to involve itself in civilian politics. ${ }^{6}$ It is argued that a high level of societal trust is likely to improve the military's ability to legitimize its interventions. ${ }^{7}$ Narli draws attention to the role of societal and cultural factors in civil-military relations by arguing that the militarist culture, which exalts "heroism, a sense of sub-ordination to the higher interests of the country, and a readiness to sacrifice oneself when necessary," is likely to facilitate deference to the military. ${ }^{8}$

If societal and cultural factors matter in civil-military relations, then the citizenry deserves greater consideration in scholarly analyses of that relationship. This work investigates factors and dynamics behind public opinion and attitude toward the military in the Turkish context. For several reasons, Turkey emerges as an excellent laboratory to conduct such research. First, presenting itself as the guardian of Kemalist principles (particularly secularism and nationalism) and state and national interests, the Turkish Armed Forces (TAF) has been frequently involved in civilian politics through direct (i.e., 1960, 1971, 1980, and 1997 interventions) and indirect (e.g., statements, briefings, private meetings) means and mechanisms. ${ }^{9}$ However, 
when the European Union (EU) recognized Turkey as an official candidate for membership during the Helsinki Summit of 1999, Turkey was forced to initiate major legal and institutional reforms, which have led to a substantial decline in the military's influence over civilian politics. ${ }^{10}$ As a result, it is argued that Turkish civilmilitary relations have entered a new era. ${ }^{11}$ In parallel to these major, unprecedented changes and developments in the last decade, we see growing scholarly attention to Turkish civil-military relations. ${ }^{12}$ These studies focus on the causes and results of the civilianization process and interactions between political and military elites in the post-Helsinki period but because they neglect public opinion and attitude, there is little analysis on how society approaches civil-military issues in this new era.

The second reason to study the Turkish case concerns the military's discourse: we see that the military strongly identifies itself with the nation. ${ }^{13}$ For instance, Retired General Aytac Yalman, Commander of the Land Forces from 2002 to 2004, once stated that the "Turkish nation is a military-nation... the Turkish Armed Forces represent the soul of the great Turkish nation." ${ }^{14}$ During the August 2008 inauguration ceremony, incoming Chief of General Staff Ilker Basbug noted that "the fundamental source of power for a military is the gun. For the Turkish military, however, it is the nation's trust and love for the military." ${ }^{15}$ Moreover, it is written on the gates of the Turkish military barracks that "A strong army means a strong Turkey." Thus, in the Turkish military's discourse, we see that military and nation are inseparable. It is unfortunate, however, that we have limited empirical knowledge of the nation's attitude toward the military as an institution and toward civil-military issues such as military intervention into civilian politics or conscription. ${ }^{16}$

One reason for this lack of knowledge about citizens' attitudes toward the military and civil-military issues is the lack of comprehensive data. Existing public opinion data sets (e.g., World Values Surveys) usually include a variable of trust or confidence in the armed forces. ${ }^{17}$ However, because there has been no comprehensive public opinion survey on Turkish civil-military relations, we have little empirical analysis of the factors and variables beyond "trust." Thus, using newly collected original and comprehensive data on public opinion and attitudes toward the military and civil-military issues, ${ }^{18}$ this study intends to provide some answers to the following questions: How do Turkish people view the military? Who supports military involvement in civilian politics? What are the determinants of public attitude vis-à-vis the military? More specifically, how do socioeconomic, political, and demographic factors shape people's approach toward the military and civil-military issues? What would be the theoretical and practical implications of such analyses?

\section{Findings/Arguments}

Our empirical findings suggest that ethnic differences matter: Turkish nationalism is associated with a strong promilitary attitude, but compared to ethnic Turks, Kurds have a much stronger anti-Turkish military attitude. And contrary to the military socialization hypothesis, military service does not really cultivate a promilitary 
attitude. Another notable finding is that societal attitude toward the military and military involvements in civilian politics have a strong partisan nature. Individuals who support Turkey's ruling, conservative Adalet ve Kalkınma Partisi (Justice and Development Party, AKP) are more critical of the military's political role. Put differently, those who support opposition parties (e.g., Cumhuriyet Halk Partisi, People's Republican Party, CHP, and Milliyetçi Hareket Partisi, Nationalist Movement Party, MHP) seem to be more likely to have a favorable attitude toward the military. Furthermore, high socioeconomic status is likely to decrease promilitary orientation.

Regarding the theoretical and practical implications of the study's empirical findings, concordance theory tends to treat the military, the political elite, and the citizenry as homogenous, monolithic entities. The findings, however, indicate that this assumption should be modified and concordance theory should take into account possible discordance within those realms. With respect to the ramifications for democratic consolidation in Turkey, several circles present Turkish democracy as a model to be followed by the Islamic world. The findings of our study, however, suggest that despite the extensive legal and institutional changes in Turkish civil-military relations in the post-Helsinki era, democratic transformation in the political culture is slow to occur. The Turkey as a model argument thus disregards the democratic deficiencies of the Turkish case.

The article proceeds as follows: the next section provides a discussion of several factors and variables that might shape public attitude toward the military and civilmilitary relations and draws some testable hypotheses. The research design section presents the data, measurement, and statistical analyses and findings. The final section discusses the ramifications of the empirical findings.

\section{Hypotheses}

Because almost no comprehensive, empirical work exists on public opinion and attitude toward civil-military relations in the Turkish case, ${ }^{19}$ this study analyzes societal attitude vis-à-vis civil-military relations from an exploratory perspective. Existing studies on public attitude toward civil-military relations in other political settings draw attention to the role of several demographic, social, political, and economic factors and variables. ${ }^{20}$ This study explores whether such factors also affect people's approaches toward civil-military relations in the Turkish context and draws inferences about civilianization and democratization processes.

\section{Ethnicity}

One might expect that ethnicity is likely to create differences in people's approaches toward the military in the Turkish case. It is a fact that the Turkish military has had tense relations with the Kurds: the military has been fighting the ethnonationalist Partiya Karkeren Kurdistan (Kurdistan Workers' Party, PKK) since the mid1980s. The armed conflict, which increased in severity in the 1990s, has resulted 
in thousands of deaths on both sides and a massive economic cost. ${ }^{21}$ Unfortunately, this fighting has also involved massive human rights violations such as torture, forced village evacuations, and extrajudicial killings, particularly in the 1990s. A state of emergency remained in force in several Kurdish provinces between 1987 and 2002 , which enhanced military pressure in the region. ${ }^{22}$ The military, which strongly advocates a unitary, centralized nation-state based on Turkish nationalism, has been critical of granting further cultural and/or political rights to the Kurds. ${ }^{23}$ Given this background, we might expect that:

Hypothesis 1: Compared to ethnic Turks, anti-Turkish military attitude should be stronger among Kurds.

\section{Religion}

When we look at the history of relations between the military and Islam, we see a mixed attitude toward Islam from the military. For instance, after the 1980 intervention, the strongly secular military embraced the ideology of the "Turkish-Islamic Synthesis." 24 Although the military presented itself as the guardian of the secular Republic, it also tried to promote religion in society by increasing the usage of Islamic discourse, introducing required religious courses in the education system, and opening new religious, vocational Imam-Hatip (prayer leader and preacher) schools. The military regime also viewed Islam as an ally against communism and used it as an instrument to contain the rise of leftist ideology in Turkey until the early 1990s. ${ }^{25}$

For the remainder of the 1990s, however, the military saw rising political Islam as a major threat against the secular Republic and so turned against it. For instance, the military believed that the pro-Islamist Refah Partisi (Welfare Party), which led the coalition government in power between 1996 and 1997, undermined the Republic's secular nature. As a result, the military mobilized secular actors (i.e., the media, civil society, and the judiciary) against the government. Under this increasing pressure, the government resigned in June 1997. During the same period, known as the February 28 process, the military also put pressure on several other pro-Islamic formations and actors (e.g., associations, business organizations, journalists, and religious brotherhoods). ${ }^{26}$ The military has also had issues with the ruling conservative AKP, particularly during its first term in office (2002-2007). For instance, ongoing court cases (also known as the Ergenekon trials) ${ }^{27}$ show that several retired and active duty military officers, including high-ranking generals were involved in coup plots against the AKP government in 2003 and 2004. In 2007, through a message from its website, the military attempted to prevent the presidency of Abdullah Gul, the then foreign minister of the AKP government. It was believed that Gul, whose wife wears a headscarf, has roots in political Islam. ${ }^{28}$

Despite its stormy relations with Islamist circles, the Turkish military is still associated with Islam in some aspects. Kaplan's ethnographic study of school textbooks displays a symbiotic relationship between the military and Islam. ${ }^{29}$ The textbooks 
view Islam as the most suitable religion for the "Turks' spirit of warfare." Kaplan further states that "both the military ethos and the Muslim faith [have] become timeless attributes of the Turkish people." ${ }^{30}$ The textbooks present the military as "the defender of the Muslim faith." 31 It is argued that since the Turks accepted Islam, they have sacrificed themselves for it by giving millions of soldiers to the religion. ${ }^{32}$ Religion is also used to exalt the military and militarism. ${ }^{33}$ The military is defined as a "Prophet's hearth" (Peygamber ocagl) $)^{34}$ and, consequently, conscription becomes a "holy" service. If a soldier dies, he becomes a martyr (i.e., dying on behalf of Islam) and martyrdom is exalted with a strong religious discourse. For example, it is believed that those who die in defense of the community of the faithful are guaranteed immediate access to Cennet (eternal paradise).

Given the contradictions in the military's relations with Islam and Islamic circles, we also explore whether and how religion-related factors matter in public opinion and attitude toward the military and civil-military issues. We therefore examine the following hypotheses:

Hypothesis 2: Religiosity increases/decreases promilitary attitude.

\section{Ideology}

Ideological factors may also shape societal popularity of the military. Huntington proposes that there is an inherent contrast and conflict between the military ethic and ideologies such as liberalism and Marxism, and an inherent similarity or compatibility between the military ethic and conservatism. In Huntington's words, the military ethic emphasizes "the permanence, irrationality, weakness, and evil in human nature. It stresses the supremacy of society over the individual and the importance of order, hierarchy, discipline, and division of function." 35 Liberalism, on the other hand, emphasizes the reason and moral dignity of the individual. Therefore, Huntington observes that in the United States, liberalism has been hostile to military institutions, functions, and values and that the conservative approach has been more sympathetic to those concepts. ${ }^{36}$ Supporting this observation, Gronke and Feaver find that conservatives in the United States are more likely to have a positive image of the military. ${ }^{37}$ Thus, whether an individual locates herself on the left or the right side of the political spectrum should have some impact (negative or positive) on her view of the military.

In the Turkish case, ideology should also matter in public opinion toward the military. During the Cold War, the main targets of Turkish military interventions were leftist groups and movements. For instance, during the 1971-1973 military regime, thousands of leftist activists were detained. We see a similar prejudice toward the left during the 1980-1983 military rule. Although rightists also experienced the wrath of the military in that period, the military promoted the right-oriented Turkish-Islamic synthesis in the country during this time. ${ }^{38}$ Thus, we might expect that:

Hypothesis 3: Antimilitary attitude will be stronger among left-oriented individuals. 


\section{Nationalism}

Another factor to take into account is nationalism. In general, nationalist thought favors a powerful nation and state and the existence of a strong army is considered essential to the existence of the nation. ${ }^{39}$ In the Turkish context, we see an even stronger association between nationalist thought and the military. Jenkins notes that "most Turks still see the military and military virtues as being inseparable from the concept of Turkishness. They take genuine pride in their reputation as fearsome soldiers and boys are taught that every Turk is born as a soldier." ${ }^{40}$ As indicated earlier, the Turkish military also presents itself as the guardian of the state and of national interests. We see a strong emphasis on nationalism and nationalist ideals in the military's discourse. These factors should promote a promilitary stance among nationalist citizens. Thus, our next hypothesis is as follows:

Hypothesis 4: Promilitary attitude should be stronger among nationalist individuals.

\section{Military Service}

We should also take into account the impact of personal experience and familiarity with the military. Treating the military as a school or educator, one approach asserts that the military inculcates young men with nationalist and militarist ideals and values (e.g., heroism, nationalism, self-sacrifice for the nation, pride in war heroes, and acceptability of warfare) during their compulsory military service. ${ }^{41}$

The military's pedagogical and socializing function is also emphasized in the Turkish context. For instance, Cizre observes:

Anti-military sentiment in Turkey has always been limited to a very small group consisting of a handful of a western-influenced ... intellectuals and human rights advocates. The factor primarily responsible for the popular perception of the military as the single most important guarantee against religious rule and political chaos is the fact that Turkey's male population has been extensively socialized into unconditional support for the military values through compulsory military service. ${ }^{42}$

The defining organizational characteristics of the TAF are based on the fact that it is a conscript army. This feature is of immense importance in integrating military values firmly into the society. Compulsory military service is an instrument that makes clear to young men who are enlisted at the age of twenty that they do not just have rights but also responsibilities and obligations to the state (emphasis added). ${ }^{43}$

Comparably, Jenkins notes:

The inculcation of the identification between nation and army was strengthened by the introduction of compulsory military service in 1927. In addition to providing military training, military service also assumed an educational and 'civilizing' role as it attempted to imbue the young conscripts with the values of the new republic. ${ }^{44}$ 
Similarly, Michaud-Emin draws attention to the socializing impact of military service:

The Turkish military is a very important socializing mechanism, as it is in Israel, and the rite of passage into manhood for both Turks and Israelis is the mandatory military service... Much of this cultural brainwashing and these socializing mechanisms might explain why Turkish society tenaciously grasps the view that the Turkish military is its most trusted and popular institution. ${ }^{45}$

Some studies, however, are critical of the military-as-school approach. Krebs, for example, argues that the military socialization argument is unconvincing and its efficacy is exaggerated. ${ }^{46} \mathrm{He}$ suggests that the model problematically assumes soldiers as passive receivers who lack the ability of reflection and asserts that it is theoretically indeterminate because familiarity with the military might also "breed consciousness of difference or even contempt":

\begin{abstract}
... even if the military were an effective inculcator of values, the messages absorbed within one social context are not necessarily portable. In modern societies, individuals have multiple identities, and there is nothing given about which will seem most appropriate... Because identity is highly contextual, one should not be surprised to see soldiers thinking in national terms while in uniform, but then adopting regional, class, gendered, religious, or ethnic perspectives at other times. ${ }^{47}$
\end{abstract}

If military service has a socializing impact on conscripts, as the military-asschool approach assumes, then performing military service would cultivate promilitary feelings and attitudes. Thus, one might anticipate that:

Hypothesis 5: Individuals who performed military service should be more likely to have a promilitary attitude.

We are also interested in the possible impact of people's support for democracy and civilian institutions. Is there a zero-sum relationship between support for democracy and civilian institutions and support for and appeal of the military? In some analyses, the answer to this question is in the affirmative. For instance, Michaud-Emin claims that the Turkish military's popularity and influence over civilian politics is reinforced by the popular societal distrust of the political system: "The very fact that politicians do not speak in a single voice and that the political system has been plagued, intermittently, by chaos and inefficiency since its inception are leading justifications for public support of the military." 48 Aydinli also assumes such a relationship, drawing attention to broad societal support for the military and a widely held view of the military as "the ultimate protector of the nation, even, if necessary, against its own political representatives." He notes that Turkish society has maintained a direct, special bond with its military, keeping its politics and politicians in a secondary position but argues that the nature of this relationship has been changing: 
Starting in the 1990s, particularly with the advance of the European Union accession process, but also in the more recent years of relative political stability and strong political leadership, society's confidence in its politicians has strengthened, and signs of a growing dissonance in societal expectations from the military have grown. ${ }^{49}$

The statements above presume a zero-sum relationship between public support for civil institutions and democratic processes and support for the military. If that really is the case, we should expect that:

Hypothesis 6: As trust in and support for democracy and democratic processes increase, confidence in and the appeal of the military would decrease.

Hypothesis 7: Those who have less trust in parliament would be more likely to trust the military.

While testing the above hypotheses, we also control for the possible impact of several other factors, such as religious sect (mezheb), ${ }^{50}$ martyred relative, political party preferences, economic satisfaction, household income, education, gender, place of residence, and age. The following section presents the data and measurement.

\section{Data and Measurement}

This study tests the above hypotheses using original data derived from a recent, comprehensive public opinion survey. The survey aimed at identifying and analyzing societal attitude toward the military and civil-military issues. While conducting the survey, we cooperated with a professional public opinion research company based in Istanbul. ${ }^{51}$ The survey was implemented through face-to-face interviews in early October 2011 with a nationwide, representative sample of 2,775 respondents. The sample was constructed using a multistage, stratified cluster-sampling technique. ${ }^{52}$

As indicated above, this research is mainly concerned with understanding and explaining a "pro-military attitude" in the Turkish context, which simply refers to respect for and societal trust in the military and agreement with its involvement in political matters. We used "confidence in armed forces," 53 "support for military rule," and "support for conscription" as the main indicators of the dependent variable (i.e., promilitary attitude). To measure the independent variables, we used the responses to the survey questions (see the Appendix for the variables, survey questions, coding, and recoding procedures). From the independent variables, we constructed an additive index only for "religious attitude." Using factor analysis, we selected the items with the highest factor loadings and then combined them to form the index (see the Appendix). ${ }^{54}$

We conducted regression analyses to test the hypotheses given above. Because the dependent variables are categorical and ordered (see the Appendix), we employed an ordered logistical regression with robust standard errors. ${ }^{55}$ The following section provides empirical analyses and findings. 


\section{Results}

\section{Trust in the Military}

Beginning with trust in the military, descriptive analyses indicate that 66.2 percent of respondents fully and 18.2 percent partly trust the military, while 14.6 percent express distrust toward it. ${ }^{56}$ Which factors and variables account for this variance and in what way? Model I in Table 1 provides ordinal-logit regression analyses of trust in the military. The findings confirm the hypothesis that compared to Turks, Kurds are less likely to trust the Turkish military. This situation appears to be a result of the legacy of military's fight against the PKK and pressure on Kurds living in the southeast, particularly in the 1990s. The results in model II and model III will also show that anti-Turkish military attitude is stronger among Turkey's Kurds, which constitutes a challenge to the notion of the military nation (asker millet). However, as expected, a higher level of Turkish nationalism is associated with a higher likelihood of trust in the military.

Another factor that shapes public trust in the military is religiosity: as religiosity increases, the likelihood of confidence in the military decreases. In other words, religious individuals have less trust in the military. This finding suggests that the "pious military" discourse does not really resonate among religious circles in Turkish society.

The military socialization hypothesis is not really supported by the findings. Military service is negatively associated with trust in the armed forces but is not statistically significant. In other words, performing military service does not seem to affect public confidence in the military one way or the other. This finding supports the views of those skeptical of the military-as-school approach.

It is striking that "support for democracy" and "trust in parliament" do not appear to reduce confidence in the military. Rather, those factors are positively associated with trust in the military. In their empirical analysis of Turkish political culture, Tessler and Altinoglu reach a similar conclusion: “... while it may appear anomalous that support for democracy is associated with confidence in such institutions of order as the military and the police, which themselves are not democratic, this, too, reflects a particularity of the Turkish case. ${ }^{, 57}$ For those authors, this is probably because Turkish society considers the military, which played a critical role in the establishment of the Turkish Republic, as the guardian of the Republic and democracy. Sakallioglu similarly notes that “... together with the civilian bureaucrats, the Turkish army historically built the Republic and subsequently modernized it along a western path. This mission turned it into the political symbol of nationhood and the instrument of preserving the nation." ${ }^{58}$ Our empirical findings demonstrate support for this perception: at least the public does not see any contradiction between supporting democracy on one hand and having a strong military on the other.

Another interesting result is the partisan attitude toward the military. As shown by the first model, compared to supporters of opposition parties (e.g., the CHP and 


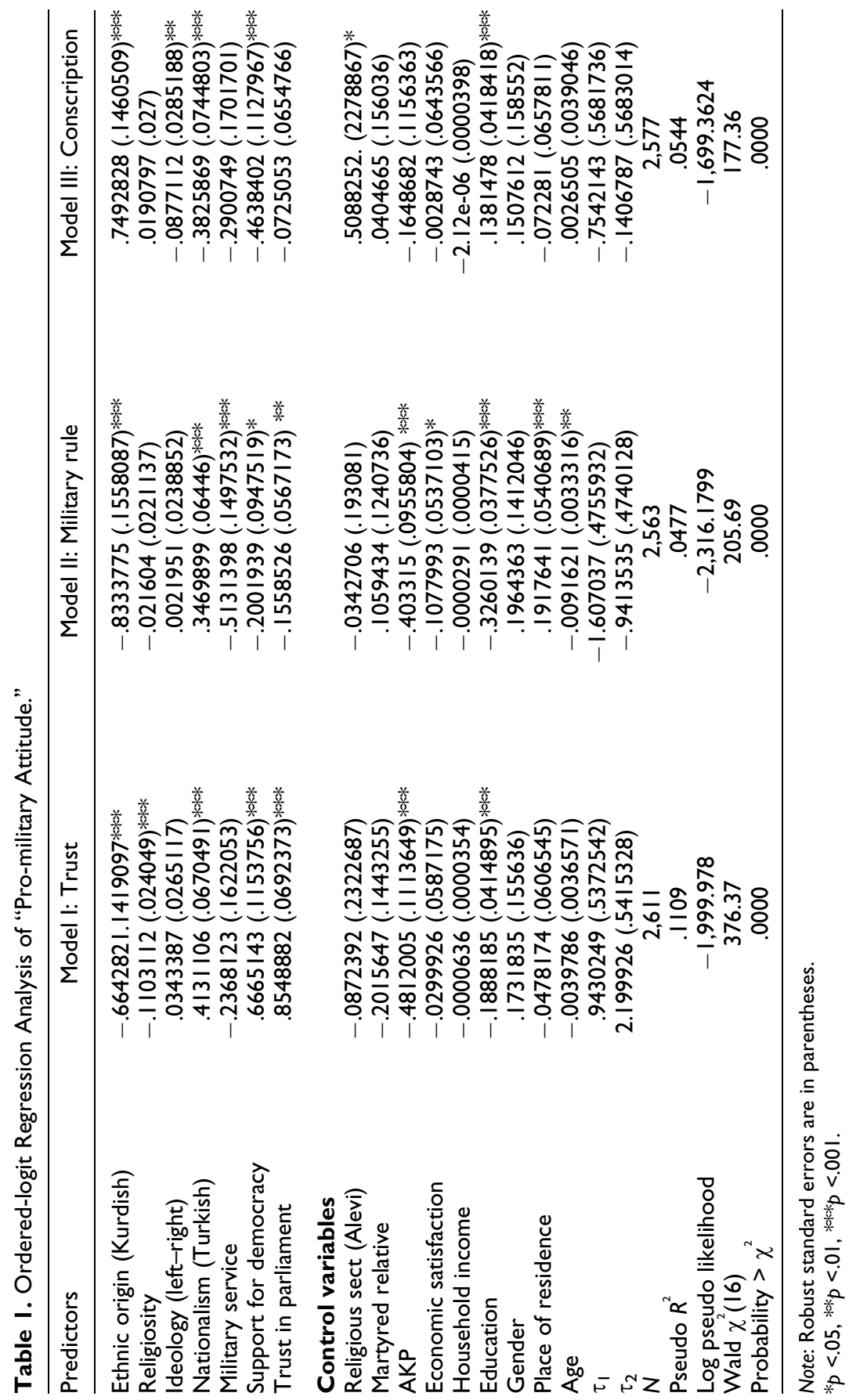


MHP), supporters of the ruling, conservative AKP are less likely to trust the military. One reason for this outcome might be the aforementioned coup allegations: since 2007, several retired and active-duty military officers have been arrested on accusations of terrorism and coup plots against the AKP government. The Ergenekon trials seem to have eroded trust in the military among supporters of the ruling party.

Finally, increases in education level decrease the likelihood of trust in the military, which implies that highly educated individuals are more likely to develop a critical attitude toward the military. Other variables (ideology, religious sect, martyred relative, economic satisfaction, household income, gender, place of residence, and age) do not have statistically significant impact on trust in the military.

\section{Support for Military Rule}

Regarding support for military rule, 13.5 percent of participants partly and 28 percent fully agree that if necessary, the military should be able to initiate a coup and rule the country. Only 55.8 percent disagree with this statement. In model II, we analyze causal factors and dynamics behind public support for military rule. As shown, ethnicity does matter: Kurds are less likely to support rule by the Turkish military. This finding should be interpreted as another indicator of the strength of the antiTurkish military attitude among Kurds. ${ }^{59}$ However, Turkish nationalists are more likely to welcome military involvement in politics. Put differently, nationalist individuals are more sympathetic to the political role of the military.

The results of model II also disprove the military socialization hypothesis. Those who performed military service are less likely to support military rule, which suggests that contact or experience with the military seems to produce a mildly negative attitude toward military involvement in political matters.

As discussed above, model I indicates that there is not really a zero-sum relationship between trust in civilian institutions and processes and trust in the military. However, model II shows that these factors reduce the likelihood of support for military rule. In other words, societal support for civilian institutions and democracy does not necessarily lead to a decline in military popularity, but it does generate a negative reaction to military involvement in political matters. This finding might be considered good news for democratization in the sense that certain circles at a mass level support a professional military on one hand and criticize a politicized, interventionist military on the other.

Partisan attitude is also visible in model II. As one might expect, voters for the ruling AKP are less likely to support military rule. A different interpretation of this finding is that the likelihood of support for military rule increases among voters for opposition parties. This striking finding provides strong evidence for the presence of partisan attitude in Turkish society toward military's political role, which is problematic for democratic consolidation (see below).

Furthermore, economic satisfaction, education, and age are also negatively associated with support for military rule. It may be that those who are satisfied with their 
current economic situation are concerned that instability might result from military intervention into politics. Similar to the findings in model I, highly educated individuals are more likely to have an antimilitary attitude and so are more critical toward military encroachment into the political sphere. These findings suggest that socioeconomic development is likely to contribute to the emergence of a more mature democratic culture. Relatively limited support for military rule among senior citizens is probably due to their negative personal experiences with previous military regimes.

\section{Conscription}

Although there may not be a direct causal relationship between conscription and democratic consolidation, analyzing the factors and dynamics behind public support for conscription should also contribute to our comprehension of the promilitary attitude in Turkey. A widespread assumption in the literature is that militarist values are strong in Turkish culture. ${ }^{60}$ Narli, for instance, points out that militarist beliefs and convictions constitute an important pillar of Turkish society. It is widely believed that "every Turk is born as a soldier," "the Turkish nation is a military nation," and "being a martyr is the highest level of exaltation." 61

Similarly, Varoglu and Bicaksiz define Turkish society as a "martial society" and draw attention to the importance of military service. In Turkish culture, military service is perceived as a national duty and a proof of masculinity. Using their words, "most Turks refer to military service as vatani görev, that is 'duty for the motherland,' rather than as mandatory service, compulsory service, conscription, or any other term that implies involuntariness." ${ }^{\prime 2}$ Inalcik, a prominent Ottoman historian, also argues that militarism and warfare are defining features of the Turkish nation:

The Turkish nation has preserved its military-nation character from the beginning of history till today ... If the Turk is ... marching on the forefronts of world history, that is because of his unshakable national characteristics, military character, his grand military virtues and his ability to engage in total war for his rights and freedom. The Turk has inherited this character from his history that goes back thousands of years. ${ }^{63}$

It is argued that the idea of the military nation and militarist values are promoted through the education system. Altinay, for instance, treats the notion of the military nation as a myth, constructed and reconstructed by state education. ${ }^{64}$ Kaplan similarly observes that the state school system fosters identification with military institutions and values. ${ }^{65}$ For instance, school textbooks state:

We Turks give importance to military service. We are even known by the world nations as a nation of soldiers (asker millet). Military service is a holy duty to the country, ensuring protection of fatherland and nation. Every Turkish youth lovingly does this duty. The Glorious Turkish Army results from heroic soldiers. When we grow up we will become soldiers and take the duty of protecting our country. ${ }^{66}$ 
Descriptive analyses seem to support the above assumptions and observations: 74 percent of respondents fully agree that the Turkish nation is a military nation (13 percent partly agree). Similarly, 74 percent object to the removal of conscription.

However, the logit analyses in model III give a more complicated picture. Kurds are more likely to support the removal of conscription, suggesting that the idea of a military nation is not that popular among that group. In other words, state and/or military indoctrination into a set of militarist values seem to have failed among Kurds. Model III also indicates that individuals with higher levels of education, leftists, and Alevis are also more likely to support the removal of conscription. Since antimilitarism generally finds more adherents among leftists and highly educated individuals, these results are not really surprising. However, only further research would shed light on why Alevis, a religious minority in Turkey, support the removal of conscription.

Interestingly, partisan attitude, which showed itself strongly regarding the political role of the military (see model II), seems to make no difference in terms of public attitude toward conscription. As seen, support for the ruling AKP does not have statistically significant impact on support for the removal of conscription. Thus, although society approaches military involvement in politics in a highly partisan way (i.e., the supporters of opposition parties tend to welcome the military in politics), this partisan manner becomes irrelevant with respect to compulsory military service. Thus, society appears to consider conscription above partisan interests.

As we would expect, Turkish nationalists are against the removal of conscription. Furthermore, as support for democracy increases, the likelihood of support for the removal of conscription declines. Other factors (i.e., religiosity, military service, trust in parliament, martyred relative, economic satisfaction, income, gender, place of residence, and age) do not have a statistically significant impact.

\section{Implications}

What would the broader theoretical and practical implications of the above findings be? First of all, they have some implications for concordance theory itself. As indicated above, by drawing attention to the autonomous role played by the social realm in civil-military relations, concordance theory helps us move beyond the civilmilitary dichotomy, dominant in the literature. This approach, however, treats the military, political, and social spheres as homogenous or monolithic entities. Our empirical findings suggest that this assumption should be modified. The Turkish case indicates that major divisions or differences might emerge among citizens (the social sphere) in their approaches toward the military and civil-military issues. Therefore, concordance theory should take into account possible discordance within the social, political, and military realms and provide some answers to the following questions: Under what conditions does concordance among the realms with internal discordance become more likely? How does concordance operate among internally 
discordant entities and to what extent does it contribute to civilian control of the armed forces?

Concerning implications for the democratization process in Turkey, it is claimed that Turkish civil-military relations have already entered into a post-guardianship era, ${ }^{67}$ given the major transformations triggered by the EU requirements in the last decade. Our empirical findings, however, indicate that despite comprehensive demilitarization or civilianization processes at the legal and institutional levels, promilitary attitudes are still strong among certain circles at a mass level. Put differently, nondemocratic elements persist within society. Therefore, despite some positive signs, transformation in the political culture is slow to occur. In their empirical research on Turkish political culture, Tessler and Altinoglu similarly conclude that " ... attitudes conducive to democracy and democratization are held by a relatively limited number of Turkish men and women, and that, accordingly, an appropriate political culture probably does not yet exist to the extent necessary for democratic consolidation." 68 This mind-set should be regarded as a major limitation because as Karabelias notes, “... a civilianization process can be successful only if a strong supportive constituency of democracy is formed at a societal level and liberal political values replace the partriarchic-oligarchic ones in the minds of the officer corps." 69

Our findings also have some implications for the arguments treating Turkey as a model for the Islamic world. It is believed that Turkey, as a Muslim country, has been able to combine Islam with secularism, democracy, and modernity, negating the argument that Islam and democracy are incompatible. Thus, many feel that Turkey could serve as a model for Islamic countries in the Middle East and North Africa. For instance, Anthony Blinkmen, Special Assistant and Senior Director for European Affairs at the National Security Council under the US President Clinton, once stated that:

Turkey sits at the crossroads or, if you prefer, atop the fault lines of the world. Because of its place ... its history ... its size ... and strength, and most important, because of what it is - a nation of mainly Islamic faith that is secular, democratic and modernizing-Turkey must be a leader and can be a role model for a large swath of the world. ${ }^{70}$

Such arguments became even more popular during the Arab Spring: Turkey is now treated as a model to be followed by Arab countries that have ousted their authoritarian regimes through mass protests and uprisings. ${ }^{71}$

The Turkey-as-a-model argument, however, tends to ignore the democratic deficits of the Turkish case. In Turkish society, the idea of democracy does receive vast public support. For instance, 95 percent of respondents in our sample agree that under all circumstances and conditions, the country should be governed as a democracy, which might be considered a strong sign of democratic consolidation. On the other hand, it is rather striking that a substantial number of people still attribute a political role to the military. For instance, 46.8 percent of respondents agree that even for issues outside security, the government should consult with the military 
before making policy decisions and taking action. ${ }^{72}$ Thus, what people understand to be "democracy" appears to be very problematic. As shown above, some seem to have a highly pragmatic and partisan attitude toward democratic procedures and institutions: as long as they serve their particular interests, they remain committed to them; if they do not, they are likely to turn to nondemocratic procedures and institutions. Bellin defines actors with such an outlook as "contingent democrats." ${ }^{73} \mathrm{We}$ see similar attitude among certain circles in Turkish society.

In brief, our empirical findings imply that there are still major hurdles to overcome before democratic consolidation is achieved in Turkey; on the attitudinal dimension, at least, we see major deficiencies (i.e., highly partisan, pragmatic and instrumental attitudes toward democracy). As claimed by several studies, consolidating democracy requires not only democratic institutions and procedures (e.g., a constitution, elections, and political parties) but also an appropriate political culture (i.e., democratic values, beliefs, and attitudes among the masses). ${ }^{74}$ If so, then this deficiency or limitation is likely to complicate the democratization process in Turkish polity for some time to come.

As a future research, this study can be extended across time and space. Conducting similar public opinion surveys in Turkey in the coming years would allow us to detect what continuities and discontinuities in Turkish public opinion toward the military are and to what extent a democratic culture emerges. Another possible extension of this research might be comparing the Turkish case with other cases. Constructing similar data sets in other countries, particularly the ones with conscript military such as Israel, Greece, Ukraine, and Norway, would allow us to identify if there is any unique feature of Turkish political culture in terms of public opinion and attitude toward the military and civil-military relations.

\section{Appendix}

\section{Variables and Measurement}

\begin{tabular}{|c|c|c|c|}
\hline Variables & $\begin{array}{l}\text { Relevant survey } \\
\text { question (translated) }\end{array}$ & Coding & Recoding, transformation \\
\hline \multicolumn{4}{|c|}{ Dependent variables } \\
\hline $\begin{array}{l}\text { Trust in the } \\
\text { military }\end{array}$ & Q26: I trust the military & $\begin{array}{l}\text { I: Disagree } \\
\text { 2: Partly agree } \\
\text { 3: Agree } \\
\text { 4: No answer }\end{array}$ & We excluded "No answer." \\
\hline $\begin{array}{l}\text { Support for } \\
\text { military rule }\end{array}$ & $\begin{array}{l}\text { Q3I: If necessary, the military } \\
\text { should be able to initiate a coup } \\
\text { and rule the country }\end{array}$ & $\begin{array}{l}\text { I: Disagree } \\
\text { 2: Partly agree } \\
\text { 3: Agree } \\
\text { 4: No answer }\end{array}$ & We excluded "No answer." \\
\hline $\begin{array}{l}\text { Support for } \\
\text { the removal } \\
\text { of conscription }\end{array}$ & $\begin{array}{l}\text { Q36: Conscription should be } \\
\text { abolished; military service should } \\
\text { be voluntary }\end{array}$ & $\begin{array}{l}\text { I: Disagree } \\
\text { 2: Partly agree } \\
\text { 3: Agree } \\
\text { 4: No answer }\end{array}$ & We excluded "No answer." \\
\hline
\end{tabular}


Appendix. (continued)

\begin{tabular}{|c|c|c|c|}
\hline Variables & $\begin{array}{l}\text { Relevant survey } \\
\text { question (translated) }\end{array}$ & Coding & Recoding, transformation \\
\hline \multicolumn{4}{|c|}{ Independent variables } \\
\hline $\begin{array}{l}\text { Ethnic origin } \\
\text { (Kurdish) }\end{array}$ & $\begin{array}{l}\text { Q48: We are all Turkish citizens but } \\
\text { we may have different ethnic } \\
\text { origins. In terms of ethnic origin, } \\
\text { how do you identify yourself? }\end{array}$ & $\begin{array}{l}\text { I: Turkish } \\
\text { 2: Kurdish } \\
\text { 3: Zaza } \\
\text { 4: Arab } \\
\text { 5: Laz } \\
\text { 6: Circassian } \\
\text { 7: Georgian } \\
\text { 8: Armenian } \\
\text { 9: Greek } \\
\text { 10: Other } \\
\text { I1: No answer }\end{array}$ & $\begin{array}{l}\text { Dummy variable for } \\
\text { Kurdish }[0,1]\end{array}$ \\
\hline $\begin{array}{l}\text { Religious } \\
\text { attitude }\end{array}$ & $\begin{array}{l}\text { QI7: Women who work as public } \\
\text { officials such as judges, } \\
\text { prosecutors, teachers, police } \\
\text { officers, etc., should be } \\
\text { allowedto wear headscarves } \\
\text { while performing their duties } \\
\text { QI8: Female students at primary } \\
\text { and secondary schools should be } \\
\text { allowed to cover their heads } \\
\text { during class } \\
\text { Q19: The legal system and laws } \\
\text { should be based on religious } \\
\text { rules }\end{array}$ & $\begin{array}{l}\text { I: Disagree } \\
\text { 2: Partly agree } \\
\text { 3: Agree } \\
\text { 4: No answer }\end{array}$ & $\begin{array}{l}\text { Using principal component } \\
\text { analysis, we constructed } \\
\text { an additive religiosity } \\
\text { index out of these } \\
\text { survey items }\end{array}$ \\
\hline $\begin{array}{l}\text { Ideology } \\
\text { (left-right) }\end{array}$ & $\begin{array}{l}\text { QI4: In terms of political position, } \\
\text { people tend to identify } \\
\text { themselves with the left, center, } \\
\text { or right. How would you identity } \\
\text { yourself? }\end{array}$ & $\begin{array}{l}\text { I: Left } \\
\text { 2: Left of center } \\
\text { 3: Center } \\
\text { 4: Right of center } \\
\text { 5: Right } \\
\text { 6: None of them } \\
\text { 7: No answer }\end{array}$ & \\
\hline $\begin{array}{l}\text { Nationalism } \\
\text { (Turkish) }\end{array}$ & $\begin{array}{l}\text { Q15: Would you define yourself as } \\
\text { a nationalist person? If so, how } \\
\text { intensely? }\end{array}$ & $\begin{array}{l}\text { I: Very } \\
\text { 2: Not very } \\
\text { 3: None } \\
\text { 4: No answer }\end{array}$ & $\begin{array}{l}\text { I: None } \\
\text { 2: Not very } \\
\text { 3: Very }\end{array}$ \\
\hline Military service & $\begin{array}{l}\text { Q5: Have you performed military } \\
\text { service? }\end{array}$ & $\begin{array}{l}\text { I: Yes } \\
\text { 2: No } \\
\text { 3: Female respondent } \\
\text { 4: No answer }\end{array}$ & $\begin{array}{l}\text { I: Yes } \\
\text { 0: No } \\
\text { 0: Female respondent }\end{array}$ \\
\hline $\begin{array}{l}\text { Support for } \\
\text { democracy }\end{array}$ & $\begin{array}{l}\text { Q28: Under all circumstances and } \\
\text { conditions, the country should be } \\
\text { governed in a democratic } \\
\text { manner }\end{array}$ & $\begin{array}{l}\text { I: Disagree } \\
\text { 2: Partly agree } \\
\text { 3: Agree } \\
\text { 4: No answer }\end{array}$ & \\
\hline $\begin{array}{l}\text { Trust in } \\
\text { parliament }\end{array}$ & Q25: I trust parliament & $\begin{array}{l}\text { I: Disagree } \\
\text { 2: Partly agree } \\
\text { 3: Agree } \\
\text { 4: No answer }\end{array}$ & \\
\hline & & & \\
\hline
\end{tabular}


Appendix. (continued)

\begin{tabular}{|c|c|c|c|}
\hline Variables & $\begin{array}{l}\text { Relevant survey } \\
\text { question (translated) }\end{array}$ & Coding & Recoding, transformation \\
\hline $\begin{array}{l}\text { Religious sect } \\
\text { (Alevi) }\end{array}$ & $\begin{array}{l}\text { Q50: How do you identify yourself } \\
\text { in terms of religious sect? }\end{array}$ & $\begin{array}{l}\text { I: Sunni Muslim } \\
\text { 2: Alevi Muslim } \\
\text { 3: Other Muslim } \\
\text { 4: Other } \\
\text { 5: Nonbeliever } \\
\text { 6: No answer }\end{array}$ & $\begin{array}{l}\text { Dummy variable for } \\
\text { Alevi }[0,1]\end{array}$ \\
\hline $\begin{array}{l}\text { Martyred } \\
\text { relative }\end{array}$ & $\begin{array}{l}\text { QI0: Is there anyone in your family } \\
\text { or among your relatives who lost } \\
\text { his life during his military service } \\
\text { or duty? }\end{array}$ & $\begin{array}{l}\text { I: No } \\
\text { 2: Yes } \\
\text { 3: No answer }\end{array}$ & \\
\hline $\begin{array}{l}\text { AKP (Political } \\
\text { party } \\
\text { preferences) }\end{array}$ & $\begin{array}{l}\text { Q12: Which party (or leader) did } \\
\text { you vote for during the June } 12 \text {, } \\
2011 \text {, general elections? }\end{array}$ & $\begin{array}{l}\text { I: AKP (AK Party) } \\
\text { 2: CHP } \\
\text { 3: MHP } \\
\text { 4: BDP } \\
\text { 5: Other } \\
\text { 6: Did not vote } \\
\text { 7: No answer }\end{array}$ & $\begin{array}{l}\text { Dummy variable for } \\
\text { the AKP }[0,1]\end{array}$ \\
\hline $\begin{array}{l}\text { Economic } \\
\text { satisfaction }\end{array}$ & $\begin{array}{l}\text { Q47: Compared to a couple of } \\
\text { years ago, how would you assess } \\
\text { your current economic } \\
\text { situation? }\end{array}$ & $\begin{array}{l}\text { I: Better } \\
\text { 2: Same } \\
\text { 3: Worse } \\
\text { 4: Do not know } \\
\text { 5: No answer }\end{array}$ & $\begin{array}{l}\text { I: Worse } \\
\text { 2: Same } \\
\text { 3: Better }\end{array}$ \\
\hline $\begin{array}{l}\text { Household } \\
\text { income }\end{array}$ & Q53: Monthly household income & & \\
\hline Education & $\begin{array}{l}\text { Q3: What is the highest level of } \\
\text { education you have attained? }\end{array}$ & $\begin{array}{l}\text { I: Illiterate } \\
\text { 2: Literate without } \\
\quad \text { degree } \\
\text { 3: Primary school } \\
\text { 4: Middle school } \\
\text { 5: High school } \\
\text { 6: University } \\
\text { 7: Master's/PhD } \\
\text { 8: No answer }\end{array}$ & \\
\hline Gender & QI: Respondent's gender & $\begin{array}{l}\text { I: Female } \\
\text { 2: Male }\end{array}$ & \\
\hline $\begin{array}{l}\text { Place of } \\
\text { residence } \\
\text { (rural-urban) }\end{array}$ & $\begin{array}{l}\text { Where the interview was } \\
\text { conducted }\end{array}$ & $\begin{array}{l}\text { 0: Village } \\
\text { I: City } \\
\text { 2: Metropolis }\end{array}$ & \\
\hline Age & Q2: How old are you? & $18-86$ & \\
\hline
\end{tabular}

\section{Acknowledgments}

The author would like to thank David P. Berlin, Gunes Ertan, Aida Just, Gareth Jenkins, Ekrem Karakoc, Rana Nelson, Burcu Ozdemir, Nil S. Satana, and Torsten Selck for very useful comments and suggestions.

\section{Author's Notes}

An earlier version of this study was presented at the 22nd World Congress of Political Science organized by International Political Science Association (IPSA) in Madrid, Spain, July 8-12, 2012. 
Research for the project "Armed Forces and Society in Turkey: An Empirical Approach" was conducted by Zeki Sarigil (principal investigator) and Yaprak Gursoy (investigator).

\section{Declaration of Conflicting Interests}

The author declared no potential conflicts of interest with respect to the research, authorship, and/or publication of this article.

\section{Funding}

The author disclosed receipt of the following financial support for the research, authorship, and/or publication of this article: This article is based on a research project, entitled "Armed Forces and Society in Turkey: An Empirical Approach" and fully funded by TUBITAK (The Scientific and Technological Research Council of Turkey).

\section{Notes}

1. Rebecca L. Schiff, "Civil-Military Relations Reconsidered: A Theory of Concordance," Armed Forces \& Society 22, 1 (1995): 13; Zeki Sarigil "Civil-Military Relations Beyond Dichotomy: With Special Reference to Turkey." Turkish Studies 12, 2 (2011): 265-78.

2. Rebecca L. Schiff, The Military and Domestic Politics: A Concordance Theory of CivilMilitary Relations (New York: Routledge, 2009), 44.

3. For more discussion on concordance theory, see Schiff, The Military and Domestic Politics.

4. Samuel P. Huntington, The Soldier and the State: The Theory and Politics of CivilMilitary Relations (Cambridge: Harvard University Press, 1994), 89.

5. Ibid., p. 89.

6. See Tanel Demirel, "Soldiers and Civilians: The Dilemma of Turkish Democracy," Middle Eastern Studies 40, 1 (2004): 127-50; Gareth Jenkins, "Continuity and Change: Prospects for Civil-Military Relations in Turkey," International Affairs 83, 2 (2007): 339-55.

7. Ozkan Duman and Dimitris Tsarouhas, "Civilianization in Greece versus Demilitarization in Turkey: A Comparative Study of Civil-Military Relations and the Impact of the European Union," Armed Forces \& Society 32, 3 (2006): 411.

8. Nilufer Narli, "Concordance and Discordance in Turkish Civil-Military Relations, 19802002," Turkish Studies 12, 2 (2011): 216. See also Ayse Gul Altinay, The Myth of the Military-nation: Militarism, Gender and Education in Turkey (New York: Palgrave Macmillan, 2004); Linda Michaud-Emin, "The Restructuring of the Military High Command in the Seventh Harmonization Package and Its Ramifications for Civil-Military Relations in Turkey," Turkish Studies 8, 1 (2007), 33.

9. See also Umit Cizre Sakallioglu, "The Anatomy of the Turkish Military's Political Autonomy," Comparative Politics 29, 2 (1997): 151-66; Frank Tachau and Metin Heper, "The State, Politics, and the Military in Turkey," Comparative Politics 16, 1 (1983): 17-33.

10. For more discussion on the impact of the European Union (EU) process on Turkish politics and democracy, see Aylin Guney and Petek Karatekelioglu, "Turkey's EU Candidacy and Civil-Military Relations: Challenges and Prospects," Armed Forces \& Society 31, 3 (2005): 439-62; Metin Heper, "The European Union, the Turkish Military 
and Democracy," South European Society and Politics 10, 1 (2005): 33-44; Paul Kubicek "Political Conditionality and European Union's Cultivation of Democracy in Turkey," Democratization 18, 4 (2011): 910-31; Ersin Kalaycioglu, “The Turkish-EU Odyssey and Political Regime Change in Turkey," South European Society and Politics 16, 2 (2011): 265-78; Ali Resul Usul, Democracy in Turkey: The Impact of EU Political Conditionality (New York: Routledge, 2010); Armagan Emre Cakir, Fifty Years of EU-Turkey Relations: A Sisyphean Story (New York: Routledge, 2011).

11. Ersel Aydinli, "A Paradigmatic Shift for the Turkish Generals and an End to the Coup Era in Turkey," Middle East Journal 63, 4 (2009): 581-96; Metin Heper, “Civil-Military Relations in Turkey: Toward a Liberal Model?" Turkish Studies 12, 2 (2011): 241-52; Zeki Sarigil, "The Turkish Military: Principal or Agent?" Armed Forces \& Society (2012); Nil. S. Satana, "Transformation of the Turkish Military and the Path to Democracy," Armed Forces \& Society 34, 3 (2008): 357-88.

12. For instance, see Ersel Aydinli, Nihat Ali Ozcan, and Dogan Akyaz, "The Turkish Military's March toward Europe," Foreign Affairs (January/February 2006): 77-90; Aydinli, "A Paradigmatic Shift for the Turkish Generals and an End to the Coup Era in Turkey"; Duman and Tsarouhas, "Civilianization in Greece versus Demilitarization in Turkey"; Umit Cizre, "Problems of Democratic Governance of Civil-Military Relations in Turkey and the European Union Enlargement Zone," European Journal of Political Research 43, 1 (2004): 107-25; Guney and Karatekelioglu, “Turkey's EU Candidacy and CivilMilitary Relations"; Heper, "The European Union, the Turkish Military and Democracy"; Heper, "Civil-Military Relations in Turkey"; Jenkins, "Continuity and Change"; Michaud-Emin, "The Restructuring of the Military High Command in the Seventh Harmonization Package and Its Ramifications for Civil-Military Relations in Turkey"; Evren Balta Paker and Ismet Akca, Turkiye'de Ordu, Devlet ve Guvenlik Siyaseti (Istanbul: Bilgi Universitesi Yayinlari, 2010); Sarigil, "Civil-Military Relations beyond Dichotomy"; Nil S. Satana, "Civil-Military Relations in Europe, the Middle East and Turkey," Turkish Studies 12, 2 (2011): 279-92; Yaprak Gursoy, "The Impact of EU-driven Reforms on the Political Autonomy of the Turkish Military," South European Society and Politics 16, 2 (2011): 293-308.

13. See also Aydinli, "A Paradigmatic Shift for the Turkish Generals and an End to the Coup Era in Turkey," 593; Mehmed A. Birand, Shirts of Steel: An Anatomy of the Turkish Armed Forces (London and New York: I. B. Tauris, 1991); Demirel, "Soldiers and Civilians," 140.

14. "Yalman: Ordu AB karşıtı olamaz," Radikal, accessed June 18, 2012, http://213.243.16. 14/haber.php?haberno $=90381$.

15. Quoted in Sarigil, "Civil-Military Relations Beyond Dichotomy,” 274.

16. For two exceptions, see Zeki Sarigil, "Deconstructing the Turkish Military's Popularity," Armed Forces \& Society 35, 4 (2009): 709-27; Mark Tessler and Ebru Altinoglu, "Political Culture in Turkey: Connections among Attitudes toward Democracy, the Military and Islam," Democratization 11, 12 (2004): 21-50.

17. Studies using such limited data sets emphasize that the military fares well in public esteem compared to several other institutions. See, for instance, Demirel, "Soldiers and 
Civilians," 138; Yilmaz Esmer, Devrim, Evrim, Statuko: Turkiye'de Sosyal, Siyasal ve Ekonomik Degerler [Revolution, Evolution and Status-quo: Social, Political and Economic Values in Turkey] (Istanbul: TESEV, 1999); Metin Heper and Aylin Guney, "The Military and the Consolidation of Democracy: The Recent Turkish Experience," Armed Forces \& Society 26, 4 (2000): 646; Gareth Jenkins, "Power and Unaccountability in the Turkish Security Forces," Conflict, Security \& Development 1, 1 (2001): 84; Jenkins, "Continuity and Change," 339; Michaud-Emin, "The Restructuring of the Military High Command in the Seventh Harmonization Package and Its Ramifications for Civil-Military Relations in Turkey," 35; H. Birsen Ors, "The Perception of the Army by Armenian Minorities Living in Turkey," Armed Forces \& Society 36, 4 (2010): 604-26; Sarigil, "Deconstructing the Turkish Military's Popularity"; Satana, "Transformation of the Turkish Military and the Path to Democracy," 371-72.

18. In conjunction with Konda Research and Consultancy, we conducted a face-to-face public opinion survey in early October 2011 with a nationwide, representative sample of 2,775 individuals. The survey was part of a broader research project, entitled "Armed Forces and Society in Turkey: An Empirical Approach" and fully funded by TUBITAK (The Scientific and Technological Research Council of Turkey).

19. For one exception see Sarigil, "Deconstructing the Turkish Military's Popularity."

20. For example, see Peter D. Feaver and Richard Kohn, eds., Soldiers and Civilians: The Civil-Military Gap and American National Security (Cambridge: MIT Press, 2001); David C. King and Zachary Karabell, The Generation of Trust: How the US Military has Regained the Public's Confidence since Vietnam (La Vergne, TN: AEI Press, 2003).

21. A recent parliamentary report shows that the fighting between Turkish security forces and the PKK has claimed around 35,000 lives since the early 1980s. Accessed January 28, 2013, http://www.radikal.com.tr/Radikal.aspx?aType=RadikalDetayV3\&ArticleID= $1118893 \&$ CategoryID $=78$.

22. PKK leader Abdullah Ocalan was captured and imprisoned in 1999. Following his orders given from prison, the PKK withdrew its forces from Turkish territory into Northern Iraq. Thus, armed conflict between security forces and the PKK substantially declined. However, fighting resumed in 2005 and has accelerated in recent years.

23. See also M. Hakan Yavuz, "Five Stages of the Construction of Kurdish Nationalism in Turkey," Nationalism and Ethnic Politics 7, 3 (2001): 18-19.

24. Sam Kaplan, "Din-u Devlet All Over Again? The Politics of Military Secularism and Religious Militarism in Turkey Following the 1980 Coup," International Journal of Middle East Studies 34, 1 (2002): 113-27.

25. Demirel, "Soldiers and Civilians," 136.

26. See also Heper and Guney, "The Military and the Consolidation of Democracy"; Jenkins, "Continuity and Change," 345.

27. Ergenekon refers to an alleged clandestine organization with members from the military, the media, academia, and civil society. Since 2007, over 300 military officers, including 60 active-duty generals and admirals, have been prosecuted and detained. They have been charged with conspiracy against the government. See Ahmet Kuru, "The Rise and Fall 
of Military Tutelage in Turkey: Fears of Islamism, Kurdish, and Communism," Insight Turkey 14, 2 (2012): 39.

28. Despite the military's opposition, Gul was elected president by the newly assembled parliament in the aftermath of the July 2007 general elections.

29. Kaplan, "Din-u Devlet All Over Again?"

30. Ibid., 120.

31. See also Tachau and Metin Heper, "The State, Politics, and the Military in Turkey," 18.

32. Kaplan, "Din-u Devlet All Over Again?" 122.

33. Militarism refers to a set of ideas and structures that exalt or praise practices and norms associated with militaries (Chenoy, in Altinay, The Myth of the Military-Nation, 2).

34. Nilufer Narli, "Civil-Military Relations in Turkey," Turkish Studies 1, 1 (2000): 118.

35. Huntington, The Soldier and the State, 94.

36. Ibid., 144-47.

37. Paul Gronke and Peter D. Feaver. "Uncertain Confidence: Civilian and Military Attitudes about Civil-Military Relations," in Soldiers and Civilians: The Civil-Military Gap and American National Security, ed. Peter D. Feaver and Richard Kohn (Cambridge: MIT Press, 2001), 129-62.

38. See also Kaplan, "Din-u Devlet All Over Again?"

39. Huntington, The Soldier and the State, 33.

40. Jenkins, "Power and Unaccountability in the Turkish Security Forces," 84. See also Aydinli, Ozcan, and Akyaz, "The Turkish Military's March toward Europe," 80.

41. See, for instance, Eugen Weber, Peasants into Frenchmen: The Modernization of Rural France, 1870-1914 (Stanford: Stanford University Press, 1976).

42. Umit Cizre, "Demythologizing the National Security Concept: The Case of Turkey," Middle East Journal 57, 2 (2003): 216-17.

43. Umit Cizre, "Ideology, Context, and Interest: The Turkish Military," in Cambridge History of Turkey, Volume 4: Turkey in the Modern World, ed. Resat Kasaba (Cambridge: Cambridge University Press, 2008), 326.

44. Jenkins, "Continuity and Change," 340.

45. Michaud-Emin, "The Restructuring of the Military High Command in the Seventh Harmonization Package and Its Ramifications for Civil-Military Relations in Turkey," 3334.

46. Ronald R. Krebs, "A School for the Nation? How Military Service Does Not Build Nations, and How It Might," International Security 28, 4 (2004): 9, 102.

47. Ibid., 108.

48. Michaud-Emin, "The Restructuring of the Military High Command in the Seventh Harmonization Package and Its Ramifications for Civil-Military Relations in Turkey," 34.

49. Aydinli, "A Paradigmatic Shift for the Turkish Generals and an End to the Coup Era in Turkey," 586-87.

50. Mezheb refers to the Muslim school of law or fiqh (religious jurisprudence). In Turkey, the vast majority of the Muslim population subscribes to Sunni mezheb (around 8085 percent), which includes Hanefi, Shafi, Maliki, and Hanbeli teachings. In Turkey, Hanefi and Shafi teachings are the most prevalent. As a non-Sunni mezhep, Alevism 
remains a minority (around 15-17 percent of the population). Alevis are considered less religious and more secular. For more on this topic, see Ali Carkoglu and Ersin Kalaycioglu, The Rising Tide of Conservatism in Turkey (New York: Palgrave Macmillan, 2009), 28-35.

51. After several meetings and workshops with researchers from Konda Resarch and Consultancy in early Spring 2011, we drafted the survey in early May 2011. To identify possible problems and difficulties with the survey questions, we consulted experts in civil-military relations and conducted pilots in the second half of May in Istanbul, Ankara, and Diyarbakir. Based on feedback from the pilots and the experts, we substantially revised the draft survey.

52. Initially, twelve regions (strata) were formed using data derived from the Turkish Statistical Institute's Address-Based Population Registration System and the results of the March 2009 local elections. Based on the number of individuals above age 18, we divided each region into three strata: village $(<4,000)$, city $(4,000-800,000)$, and metropolis $(>800,000)$. Next, districts were identified in each stratum $(51,301$ districts in total) and among them, 154 districts (clusters) were randomly selected with computer assistance. In each district, eighteen individuals on average from randomly selected households were interviewed face-to-face by Konda researchers.

53. This study does not really assume a direct, causal relationship between societal trust toward military and support for military intervention. What is assumed, however, is that an interventionist military might relatively easily legitimize its attempts to shape civilian politics in a political culture with militarist elements and values. That is why trust in military emerges as an important factor. In the absence of high level of trust, it is less likely to develop promilitary attitude. Thus, this study treats societal trust toward military as one of the constitutive elements of promilitary attitude.

54. Categories such as no answer and don't know were excluded from the dependent variables. Regarding the independent variables, because such answers constituted very small percentages, the statistical estimations with or without those options are identical.

55. See Scott J. Long, Regression Models for Categorical and Limited Dependent Variables (Thousand Oaks: Sage, 1997); Scott Menard, Applied Logistic Regression Analysis (Thousand Oaks: Sage, 2002).

56. In Turkey, trust in the military is relatively higher than trust in parliament ( 24.3 percent express distrust, 20.6 percent express partial trust, and 53.6 percent express full trust in parliament). However, it should be noted that trust in the military is also higher than trust in civilian institutions (e.g., the parliament) in European countries. Thus, Turkey is not really an exception in that sense. However, despite declining trend, public trust in the Turkish military is still higher than the average level of public trust in the army in EU countries. For comparative data, see http://ec.europa.eu/public_opinion/cf/index_en.cfm. Accessed June 27, 2013.

57. Tessler and Altinoglu, "Political Culture in Turkey," 35.

58. Sakallioglu, "The Anatomy of the Turkish Military's Political Autonomy," 154.

59. This finding does not necessarily mean that Kurds have a relatively more democratic attitude; it just shows that they are more critical toward the Turkish military. 
60. For a historical and comparative analysis of militarism in the Turkish context, see Murat Belge, Militarst Modernlesme: Almanya, Japonya ve Türkiye (Istanbul: Iletisim, 2011).

61. Narli, "Concordance and Discordance in Turkish Civil-Military Relations, 1980-2002," 216. See also Aydinli, Ozcan, and Akyaz, "The Turkish Military's March toward Europe," 80; Demirel, "Soldiers and Civilians," 140.

62. A. Kadir Varoglu and Adnan Bicaksiz, "Volunteering for Risk: The Culture of the Turkish Armed Forces," Armed Forces \& Society 31, 4 (2005): 584-85.

63. Quoted in Altinay, The Myth of the Military-nation, 30.

64. Ibid.

65. Kaplan, "Din-u Devlet All Over Again?”; Sam Kaplan, The Pedagogical State: Education and Politics of National Culture in post-1980 Turkey (Stanford: Stanford University Press, 2006). See also Jenkins, "Continuity and Change," 340.

66. Quoted in Kaplan, "Din-u Devlet All Over Again?" 116.

67. See Sarigil, "The Turkish Military"

68. Tessler and Altunoglu, "Political Culture in Turkey," 43.

69. Gerassimos Karabelias, "Dictating the Upper Tide: Civil-Military Relations in the PostÖzal Decade, 1993-2003," Turkish Studies 9, 3 (2008): 468.

70. Quoted in Meliha Benli Altunisik, "The Turkish Model and Democratization in the Middle East," Arab Studies Quarterly 27, 1-2 (2005): 45.

71. For further discussion on this issue, see Asli Bali, "A Turkish Model for the Arab Spring? " Middle East Law and Governance 13, 1-2 (2011): 24-42; Peter Kenyon, "The Turkish Model: Can It Be Replicated?” National Public Radio (2012), http://www.npr.org/2012/ 01/06/144751851/the-turkish-model-can-it-be-replicated; Accessed June 28, 2013. Alon Liel, "The Turkish Model and the Arab Spring," Palestine-Israel Journal 18, 1 (2012); Paul Salem, Turkey's Image in the Arab World (Istanbul: TESEV, 2011); Ahmet Kuru, Muslim Politics without an Islamic State: Can Turkey's Justice and Development Party Be a Model for Arab Islamists (Policy Briefing) (Doha: Brookings Doha Center, 2013).

72. For a similar finding, see Ali Carkoglu and Binnaz Toprak, Degisen Turkiye'de Din, Toplum ve Siyaset (Istanbul, TESEV, 2006).

73. Eva Bellin, “Contingent Democrats: Industrialists, Labor, and Democratization in Latedeveloping Countries," World Politics 52, 2 (2000): 125-205.

74. For instance, see Gabriel A. Almond and Sidney Verba, The Civic Culture: Political Attitudes and Democracy in Five Nations (California: Sage, 1989); Larry Diamond, ed., Political Culture and Democracy in Developing Countries (Colorado: Lynne Rienner, 1994); Juan J. Linz and Alfred Stepan, "Toward Consolidated Democracies," Journal of Democracy 7, 2 (1996): 16; Larry Diamond, Developing Democracy: Toward Consolidation (Maryland: The Johns Hopkins University Press, 1999); Ronald Inglehart, "Culture and Democracy"; Lawrence E. Harrison and Samuel Huntington, eds., Culture Matters: How Values Shape Human Progress (New York: Basic Books, 2000); Richard Rose, William Mishler, and Christian Haerpfer, Democracy and Its Alternatives: Understanding Post-communist Societies (Baltimore, MD: Johns Hopkins University Press, 1998). 


\section{Author Biography}

Zeki Sarigil is an assistant professor of political science at Bilkent University, Ankara, Turkey. His research interests include ethnonationalism, civil-military relations, institutional theory, and Turkish politics. His articles were published in such journals as Armed Forces \& Society, European Journal of International Relations, Nations and Nationalism, Ethnic and Racial Studies, Critical Policy Studies, Mediterranean Politics, and Turkish Studies. 